\title{
Short Duration Grazing at the Texas Experi- mental Range: Effects on Forage Quality
}

\author{
R.K. HEITSCHMIDT, R.A. GORDON, AND J.S. BLUNTZER
}

\begin{abstract}
Variation in percent crude protein $(\% \mathrm{CP})$ of available forage was examined at the Texas Experimental Ranch as a function of grazing treatment, plant species, physiological age of plant tissue, and season. Results indicate that $\% \mathrm{CP}$ content varied as much as function of physiological age of plant tissue as a function of plant species. Although quantity of crude protein of total standing crop averaged significantly more in an ungrazed treatment than in a short duration grazing treatment, \% CP was generally greater in the grazed than the ungrazed treatment. It is suggested that an increase in quality of forage may be a primary mechanism facilitating energy flow through short duration grazing systems whereby dramatic increases in livestock carrying capacity may be realized.

Various parameters may be utilized to reflect quality of a forage. For example, low quality forage has often been associated with reduced levels of crude protein, phosphorus, and dry matter digestibility and increased levels of crude fiber and lignin (Streeter et al. 1968, Sims et al. 1971, Wallace et al. 1972). But regardless of the parameter utilized to measure the quality of a forage, each parameter can be related in some manner to the potential net energy gain of the consuming animal. Thus, forage quality may be defined in general terms as any forage parameter altering the net energy gain of the consuming animal.

Since quality of forage declines with plant maturation (Cook and Harris 1968, Sims et al. 1971, Stoddart et al. 1975), any grazing management practice reducing plant aging processes should increase the quality of forage available to the grazing animal. The objective of this study was to evaluate the effect of short duration

\footnotetext{
Authors are associate professor and former research associates, Department of Vernon 76384. ment of Soils and Crop Sciences, Texas A\&M University Research and Extension Center, Amarillo, for chemical analysis of forage samples and to the Swen R. Swenson Cattle Company for providing the land, livestock and facilities for this research

Report is published with approval of the Director, Texas Agricultural Experiment
} Range Science, Texas A\&M University Research and Extension Center, Box 1658,

Appreciation is expressed to Dr. D.J. Undersander, assistant professor, Departproject. Station as TA 16358 .
\end{abstract}

grazing (SDG) on quality of standing crop as mea sured by percent crude protein content. A basic underlying hypothesis was that a significant increase in forage quality may at least in part account for the dramatic increases in livestock carrying capacity reported by Savory (1978) following implementation of a SDG system (Heitschmidt et al. 1981a).

\section{Study Area and Methods}

Data were collected at the Texas Experimental Ranch during the 1978 growing season as part of a preliminary study to evaluate the effects of SDG on vegetation growth dynamics and livestock weight gain (Heitschmidt et al. 1982a, 1982b). Sample plots consisting of two $30 \times 60-\mathrm{m}$ replicates located within a fenced exclosure (ungrazed treatment) and in one pasture of a 10-pasture SDG system (grazed treatment). The SDG system was stocked with growing heifers at a rate of 0.24 ha/ AUM from early April to early October. Long-term cow-calf performance data at the ranch indicate a moderate rate of stocking for mature cows under year-long continuous grazing is near 0.54 ha/AUM (Heitschmidt et al. 1982c). Rate of rotation of the heifers was such that the grazed treatment plot was grazed every 35 to 42 days for 3 to 7 days.

Plant tissue for percent crude protein (\% CP) determinations was initially harvested for estimates of standing crop (Heitschmidt et al. 1982b). Standing crop was harvested by species in 10 randomly located $0.25-\mathrm{m}^{2}$ quadrats in each replicate on each sample date. Tillers were separated by stage of maturity into either live, recent dead (current year's production), or old dead (previous year's production). Samples were oven dried at $60^{\circ} \mathrm{C}$ to a constant weight, weighed, and then ground in a Wiley mill utilizing a 40-mesh screen. Samples were collected in both treatments at the beginning and end of the growing sea son and immediately prior to each grazing event. Another sample was collected in the grazed treatment after each grazing event.

Because quantity of plant material within a replication was often insufficient for laboratory analyses, duplicate material within a 
treatment was combined and replications were disregarded. Still, after combining only four species yielded sufficient biomass for $\%$ CP determinations for all age categories across several dates. These species were and their text reference codes are: Texas wintergrass (Stipa leucotricha Trin. and Rupr.), STLE; Texas cupgrass [Eriochloa sericea (Scheele) Munro], ERSE; sideoats grama [Bouteloua curtipendula Michx.) Torr.], BOCU; and buffalograss [Buchloe dactyloides (Nutt.) Engelm], BUDA. Biomass samples of lesser species were combined into phenologically similar species groups. Species groups and their text reference codes are warmseason grasses (WSGR) and warm-season forbs (WSFO). After combining, \% CP was determined in duplicate by microkjeldahl techniques (A.O.A.C. 1970) and expressed on a dry matter basis. For a more detailed description of both the study area and field sampling procedures, see Heitschmidt et al. (1982a, 1982b).

Standard analysis of variance $(\mathrm{AOV})$ procedures were utilized for statistical analyses with mean separation following Tukey $Q$ procedures (Snedecor and Cochran 1967). Variables included in the AOV models were treatment, date, species, and age category. Three treatments were compared: ungrazed, before grazing, and after grazing.

\section{Results}

Statistical analyses indicated that the $\% \mathrm{CP}$ of similar aged tissue for any given species was not significantly $(P<0.05)$ altered by grazing treatment. However, significant $(P<0.05)$ differences were found to exist among species, categories, and dates. Live tissue of WSFO averaged $14 \% \mathrm{CP}$ which was significantly $(P<0.01)$ greater than all other species or species group (Table 1). A portion of the differences among species in \% CP of the live tissue was attributed to sampling error. For example, a considerable portion of the individual tillers of both BUDA and BOCU consisted of both live and recent dead tissue. Since separation into the three age categories was done in the field by individual tiller, a greater percentage of recent dead tissue probably contaminated the live tissue for these two species than for any other species.

Percent CP of WSFO remained significantly $(P<0.01)$ higher as plants matured (recent dead) with the $\% \mathrm{CP}$ of BOCU remaining the lowest (Table 1). Percent CP of old dead varied little among species except for WSFO's which were significantly $(P<0.01)$ less than all other species (Table 1).

Table 1. Crude protein (\%) of four plant species and two phenologically similar species groups for three age categories of tissue averaged across grazing treatments and dates.

\begin{tabular}{lcccccc}
\hline \hline & \multicolumn{5}{c}{ Species/species group } \\
\cline { 2 - 7 } Category & WSFO & ERSE & STLE & WSGR & BUDA & BOCU \\
\hline Live & $14.0 \mathrm{a}^{2}$ & $11.9 \mathrm{~b}$ & $11.7 \mathrm{~b}$ & $10.3 \mathrm{bc}$ & $9.7 \mathrm{c}$ & $9.1 \mathrm{c}$ \\
Recent dead & $9.0 \mathrm{a}$ & $7.4 \mathrm{bc}$ & $7.7 \mathrm{ab}$ & $8.3 \mathrm{ab}$ & $7.4 \mathrm{bc}$ & $6.1 \mathrm{c}$ \\
Old dead & $4.9 \mathrm{a}$ & $6.4 \mathrm{c}$ & $6.2 \mathrm{c}$ & $6.3 \mathrm{c}$ & $5.9 \mathrm{bc}$ & $5.5 \mathrm{~b}$ \\
\hline
\end{tabular}

'WSFO = Warm season forbs; ERSE - Eriochloa sericea STLE = Stipaleucotricha; WSGR $=$ Warm season grasses; BUDA $=$ Buchloe dactyloides; BOCU $=$ Bouteloua curtipendula.

2Means in a row followed by same letter are not significantly different at $P<0.05$.

There were no significant $(P<0.05)$ differences among dates in $\%$ $\mathrm{CP}$ of the live tissue although as the live tissue aged \% CP tended to decline (Table 2). This trend was evident during April, May, and June and again during September and October

Percent CP of the recent dead tissue declined significantly $(P<0.05)$ with age (Table 2$)$. The significant $(P<0.01)$ increase in $\%$ $C P$ in old dead tissue from April to June was most likely the result of sampling error in that a small portion of recent dead tissue may have been misclassified as old dead in May and June. This small amount of recent dead tissue could have significantly increased avera ge $\% \mathrm{CP}$ values for old dead tissue since total quantities of old dead tissues were small by May and June (Heitschmidt et al. $1982 b)$ able 2. Crude protein (\%) for three age categories of tissue on six dates averaged across four species and two phenologically similar species groups.

\begin{tabular}{lcccccc}
\hline \hline & \multicolumn{8}{c}{ Month } \\
\cline { 2 - 7 } Category & Apr. & May & June & Aug. & Sept. & Oct. \\
\hline Live & $11.9 \mathrm{a}^{1}$ & $10.3 \mathrm{a}$ & $10.5 \mathrm{a}$ & - & $11.9 \mathrm{a}$ & $11.0 \mathrm{a}$ \\
Recent dead & - & - & - & $8.0 \mathrm{a}$ & $7.8 \mathrm{ab}$ & $7.2 \mathrm{~b}$ \\
Old dead & $5.4 \mathrm{a}$ & $5.9 \mathrm{~b}$ & $6.3 \mathrm{c}$ & & - & - \\
\hline
\end{tabular}

IMeans in a row followed by same letter are not significantly different at $P<0.05$.

Standing crude protein for each age category on each sample date within each treatment was calculated (Fig. 1) by multiplying \% CP of individual species by their respective dry weights (Heitschmidt et al. 1981b). Statistical analyses indicated significant $(P<0.05)$ differences among treatments in quantity of total standing CP. Standing CP averaged $18.8,14.5$, and $10.5 \mathrm{~g} / \mathrm{m}^{2}$ for the ungrazed treatment, the grazed treatment prior to grazing, and the grazed treatment immediately after grazing, respectively. Relative contribution of each age category to total standing crop of crude protein generally reflected a greater contribution of live tissue to the total in the grazed than the ungrazed treatment.

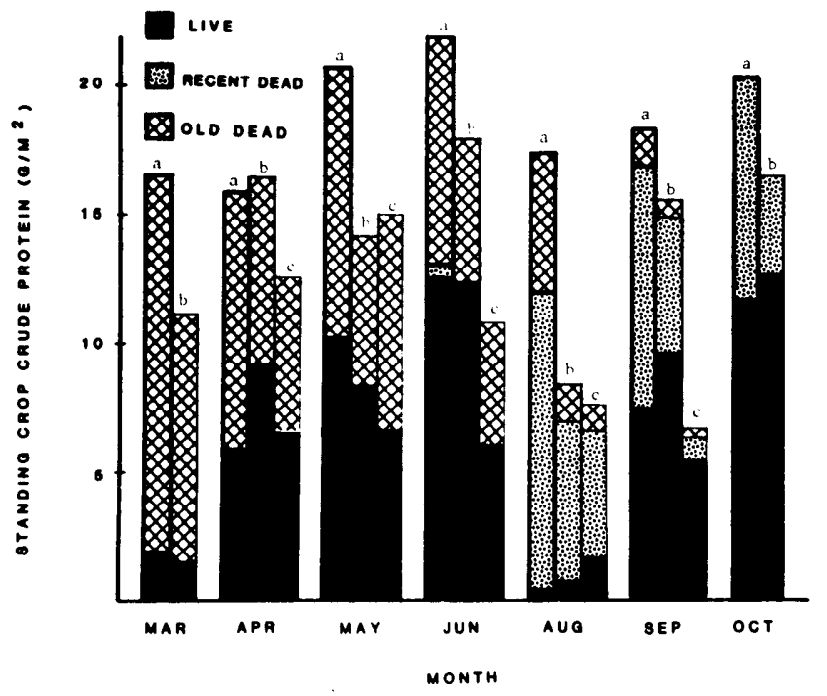

Fig. 1. Total standing crop crude protein $\left(\mathrm{g} / \mathrm{m}^{2}\right)$ for seven dates in the ungrazed treatment (a) and the short duration grazing treatment prior to grazing (b) and after grazing (c) for three age categories of plant tissue.

Average \% CP of total standing crop was calculated by dividing grams of crude protein by grams of total standing crop (Fig. 2). Although differences among treatments were not statistically significant $(P<0.05), \% \mathrm{CP}$ in the grazed treatment always exceeded that of the ungrazed treatment with the exception of August. In addition, \% CP was always less at the conclusion of each grazing event than before grazing indicating the heifers selectively grazed the higher quality forage.

\section{Discussion and Conclusion}

These data suggest that \% CP of forage is primarily a function of the physiological age of the plant tissue. Although \% CP may vary as a function of species (Cook and Harris 1968, Sims et al. 1971, Willard and Schuster 1973), these data indicate that greater differences often occur as a function of age of tissue than as a function of species. The effects of such factors as fertilization, climate, and range site on forage quality (Sims et al. 1971, Goetz 1975) can at least in part, be attributed to alterations in the live/dead tissue ratio, which is a function of the physiological age of the plant. Thus any management practice reducing rate of leaf senescence or stimulating growth should increase average forage quality. 


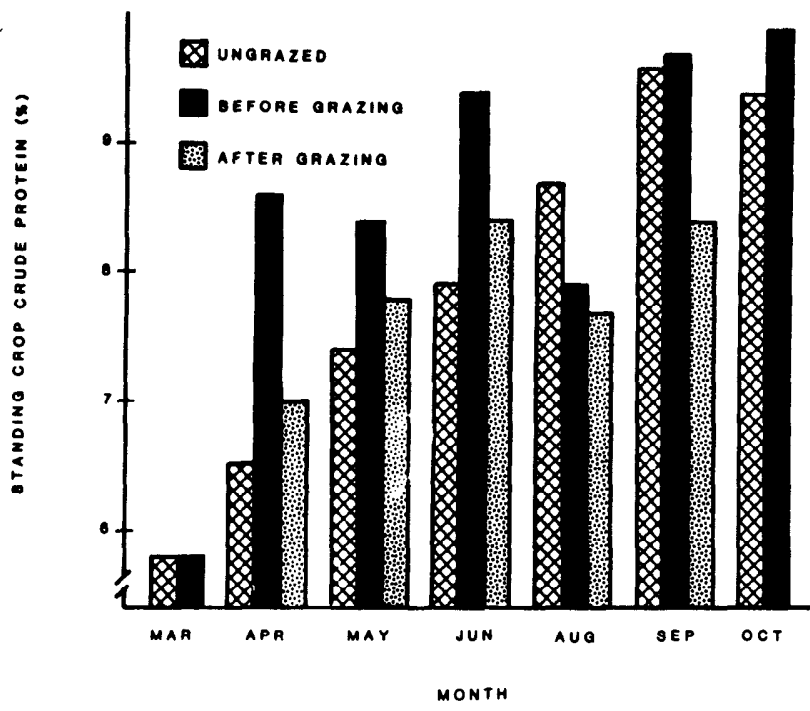

Fig. 2. Average crude protein (\%) of total standing crop for seven dates in the ungrazed treatment and the short duration grazing treatment prior to grazing and after grazing.

A reduction in rate of leaf senescence and increased rates of vegetative growth have both been reported following actual or simulated grazing (McNaughton 1979) while increases in $\% \mathrm{CP}$ of leaf tissue following various levels of defoliation have been reported by others (Kathju et al. 1979). In each instance, severity and frequency of tiller defoliation have caused a plant response which would increase forage quality. Since severity and frequency of tiller defoliation are major factors controlled by SDG (Heitschmidt et al. 1982a), it can be assumed that a properly implemented SDG system will increase average quality of forage available to the grazing animal if rate of rotation provides the animals an opportunity to graze pasture regrowth prior to the onset of appreciable amounts of plant senescence.

Although \% CP is not a direct measure of digestible energy, a positive relationship does exist. Allison (1978) evaluated changes in in vitro digestible organic matter, $\% \mathrm{CP}$, and digestible energy of cow diets at the Texas Experimental Ranch as a function of grazing pressure. Utilizing his values, digestible energy $(\mathrm{kcal} / \mathrm{kg}$ ) was predictable from $\%$ CP values from the model $y=1273+104 x$ where $y$ equaled digestible energy and $x$ equaled $\% \mathrm{CP}\left(R^{2}=0.87, P<0.01\right.$, d.f. $=35$ ). Although the quantitative values established by this regression are of limited value to this study, the positive relationship established between digestible energy and \% CP supports a general hypothesis that grazing may facilitate energy flow through an ecosystem (McNaughton 1976). In essence, we suggest that an increase in quality of forage may prove to be a primary mechanism facilitating energy flow through a SDG system if a sustained increase in carrying capacity is realized.

\section{Literature Cited}

Allison, C.C. 1978. Forage intake of cattle as affected by stocking pressure. Ph.D. Diss. Texas A\&M University, College Station. 213 p.

A.O.A.C. 1970. Official methods of a nalysis (1 l th ed.). Ass. of Official Agr. Chem., Washington, D.C. 1015 p.

Cook, C.W., and L.E. Harris. 1968. Nutritive value of seasonal ranges. Utah Agr. Exp. Sta. Bull. No. 472. 55 p.

Goetz, Harold. 1975. Influence of site and fertilization on protein content of native grasses. J. Range Manage. 28:380-385.

Heitschmidt, R.K., J.R. Frasure, D.L. Price, and L.R. Rittenhouse 1982a. Short duration grazing at the Texas Experimental Ranch. I. Weight gains of growing heifers. J. Range Manage. 35:375-379.

Heitschmidt, R.K., D.L. Price, R.A. Gordon, and J.R. Frasure. 1982b. Short duration grazing at the Texas Experimental Ranch: Effects on aboveground net primary production and seasonal growth dynamics. J. Range Manage. 35:367-372.

Heitschmidt, R.K., M.M. Kothmann, and W.J. Rawlins. 1982c. Cow-calf response to stocking rates, grazing systems and winter supplementation. J. Range Manage. 35:204-210.

Kathju, S., K.A. Shankarnarayan, A.N. Lahiri and S.P. Vyas. 1979. Effects of fertilization and clipping on protein in leaves of desert grasses. Expl. Agr. 15:103-106.

McNaughton, S.J. 1979. Grazing as an optimization process: Grassungulate relationships in the Serengeti. Amer. Natur. 113:691-703.

Savory, Allan. 1978. A holistic approach to range management using short duration grazing. p. 555-557. In: Proc. Ist Internat. Rangeland Cong. (Ed. by D.N. Hyder) Soc. Range Manage. Denver, Colo.

Sims, P.L., G.R. Lovell, and D.F. Hervey. 1971. Seasonal trends in herbage and nutrient production of important sandhill grasses. J. Range Manage. 24:55-59.

Snedecor, G.W., and W.C. Cochran. 1967. Statistical methods (6th ed.) lowa St. Univ. Press., Ames. 593 p.

Stoddart, Laurence A., Arthur D. Smith, and Thadis W. Box. 1975. Range management. McGraw-Hill Book Co. 532 p.

Streeter, C.L., D.C. Clanton, and O.E. Hoehne. 1968. Influence of advance in season on nutritive value of forage consumed by cattle grazing Western Nebraska native range. Univ. of Neb. Agr. Exp. Sta. Res. Bull. No. 227. $21 \mathrm{p}$.

Wallace, J.D., D.N. Hyder, and G.M. Van Dyne. 1972. Salivary contamination of forage selected by esophogeal fistulated steers grazing sandhill grassland. J. Range Manage. 25:185-187.

Willard, E. Earl, and J.L. Schuster. 1973. Chemical composition of six Southern Great Plains grasses as related to season and precipitation. J. Range Manage. 26:37-39. 